ANNA LANDAU-CZAJKA

https://orcid.org/0000-0003-2090-9855

Instytut Historii im. Tadeusza Manteuffla Polskiej Akademii Nauk

\title{
KOTY W SPOŁECZEŃSTWIE II RZECZYPOSPOLITEJ
}

Zarys treści: Artykuł przedstawia stosunek społeczeństwa II Rzeczypospolitej do kotów, a szerzej - do zwierzat, przede wszystkim zaś próbuje odpowiedzieć na pytanie, czy podczas międzywojennego dwudziestolecia nastapiła w tej kwestii zauważalna zmiana. Ukazuje warunki, w jakich żyły domowe koty, okrucieństwo, jakiego dopuszczano się wobec tych zwierząt, sposoby ich wykorzystywania (np. w przemyśle futrzarskim). Pozwala też odpowiedzieć na pytanie, dlaczego wiele osób obawiało się kotów i uznawało je za zwierzęta groźne.

The content outline: The article presents the attitude towards cats - and more broadly to all animals - in the society of the Second Polish Republic, and seeks to answer the question of whether any considerable evolution in this aspect could be noticed within the twenty years of the state's existence. It discusses the living conditions of domestic cats, the issue of cruel treatment of these animals, their use as a resource (e.g. in the fur industry). The analysis answers the question of why so many people feared cats and considered them to be dangerous.

Słowa kluczowe: II Rzeczpospolita, zwierzęta, koty, normy społeczne

Keywords: Second Polish Republic, animals, cats, social norms

\section{Wstęp}

Animal studies to bardzo modny obecnie kierunek badań, szczególnie na zachodzie Europy i w Stanach Zjednoczonych. Ukazuje się wiele książek dotyczących miejsca zwierząt w kulturze, społeczeństwie, stosunków między zwierzętami a ludźmi, wykorzystywaniu zwierząt, traktowaniu ich i okrucieństwie wobec nich. Niektórzy autorzy staraja się przedstawić „zwierzęcy punkt widzenia”, czyli dzieje ludzi, a może raczej cywilizacji widziane poprzez pryzmat losów zwierząt. Jednak 
większość tych refleksji koncentruje się na zwierzętach bardziej użytecznych i wykorzystywanych przez ludzi niż koty. A więc raczej będa to konie, psy czy zwierzęta przeznaczone do hodowli. Koty nie wydaja się być w tym przypadku przedmiotem szczególnego zainteresowania. W obszernej pracy Margo DeMello Animals and Society. An Introduction to Human-Animal Studies zwierzętom domowym poświęcono tylko jeden, krótki rozdział, dosyć ogólnikowy, przedstawiający m.in. zwięzła historię udomowienia zwierzą, ze wskazaniem, że dopiero ok. XVIII w. zaczęto trzymać $\mathrm{w}$ domu zwierzęta wyłącznie dla przyjemności i nadawać im imiona ${ }^{1}$.

W Polsce animal study zainteresowano się stosunkowo niedawno. Działajace w Siedlcach Wydawnictwo Naukowe Instytutu Kultury Regionalnej i Badań Literackich im. Franciszka Karpińskiego od kilku lat publikuje serię poświęconą roli zwierząt (dotychczas ukazały się tomy o koniach, kotach i psach, w przygotowaniu o ptakach), ale uwaga autorów koncentruje się głównie na przedstawianiu zwierząt w literaturze, sztuce, muzyce, mniej zaś na ich funkcjonowaniu w społeczeństwie ${ }^{2}$. Na temat wzajemnego stosunku właścicieli i ich ulubieńców ukazała się po polsku praca Krzysztofa Tomasza Koneckiego Ludzie i ich zwie$r z e ̨ t a^{3}$. Znajduje się w niej bardzo interesujacy rozdział na temat zwierząt w polskich rodzinach, ale - oparty na badaniach socjologicznych dotyczy oczywiście rodziny współczesnej, a nie okresu międzywojennego. Daje jednak możliwość porównania tych okresów.

Choć zainteresowanie domowymi zwierzętami wzrasta, to niekoniecznie przekłada się to na badania nad miejscem kotów w społeczeństwie i ich postrzeganiem. Kot, współcześnie uznawany powszechnie za zwierzę domowe, jeszcze nie tak dawno tylko częściowo był zaliczany do tej

${ }^{1}$ M. DeMello, Animals and Society. An Introduction to Human-Animal Studies, New York 2012, s. 146-169. W literaturze zachodniej to obecnie bardzo popularny kierunek badań - trudno w krótkim artykule wymienić choćby najważniejsze publikacje. Jednak koty zajmują stosunkowo niewiele miejsca nawet $\mathrm{w}$ publikacjach poświęconych zwierzętom w społeczeństwie. Na przykład w bardzo znanej monografii Érica Barataya Zwierzęta w okopach. Zapomniane historie, tłum. B. Brzezicka, Gdańsk 2017, omawiającej losy zwierząt na frontach, są rozdziały poświęcone koniom, psom, gołębiom, o kotach jest tylko jeden podrozdział w części „Widzowie na froncie”, dotyczący bezdomnych kotów w okopach i temu, jak zajmowali się nimi żołnierze. Jednak o wojskowej działalności kotów nie dowiemy się niczego, we wstępie znajdują się szacunki liczbowe zmobilizowanych zwierząt, kotów wśród nich nie ma.

${ }^{2}$ Zob. A. Landau-Czajka, Między bajka a rzeczywistościa. Kot w pisemkach dla dzieci w II Rzeczypospolitej, w: Kot w literaturze, kulturze, języku i mediach, red. E. Borkowska, A. Borkowski, M. Długołęcka-Pietrzak, S. Sobieraj, Siedlce 2018, s. 355-371.

${ }^{3}$ K.T. Konecki, Ludzie i ich zwierzęta. Interakcjonistyczno-symboliczna analiza społecznego świata właścicieli zwierzat domowych, Warszawa 2005. 
kategorii. Koty bywały oczywiście ulubieńcami rodziny, ale były także naturalnymi mieszkańcami miast (o „bezdomności” kotów dopiero zaczynano mówić), szkodnikami w lasach i zwierzętami uznanymi potencjalnie za niebezpieczne, a także użytkowymi, hodowanymi nie dla przyjemności, ale do pracy lub po prostu na futro. Były zarazem domowe, użytkowe i dzikie.

Ponadto nie powstały dotąd prace ukazujace sposób traktowania zwierząt domowych w II Rzeczypospolitej. Na przykładzie kotów najlepiej można przedstawić stosunek społeczeństwa do zwierzęcia jako takiego, a nie do zwierzęcia jako własności. Koty nie miały wartości materialnej, poza nielicznymi egzemplarzami rasowymi. Posiadanie kota nie zależało od zamożności, nie trzeba było płacić za nie podatku (jak za psy). Psa trzeba było karmić, jadł więcej niż kot, przy czym ten ostatni częściowo sam organizował sobie pożywienie. Psy pełniły także funkcje użytkowe. Wprawdzie koty łowiły gryzonie, ale niekoniecznie $\mathrm{w}$ wielkim mieście, poza tym robiły to instynktownie, nie wymagały szkolenia, jednego można więc było zastapić innym. Jeśli o koty się troszczono, to ze względów humanitarnych czy uczuciowych, a nie dlatego, że dbano o swoją własność.

Celem tego artykułu jest przedstawienie stosunku do kotów, a szerzej - do zwierząt, społeczeństwa, a nie urzędowych rozwiązań dotyczących traktowania zwierząt, przede wszystkim zaś zbadanie, czy $\mathrm{w}$ czasie dwudziestolecia nastapiła w tym względzie dająca się zauważyć zmiana. Trudno jednak znaleźć rzetelne źródła dotyczące położenia i traktowania kotów. W pamiętnikach zdarzaja się opisy zwierząt domowych, ich zachowania, a czasem nawet opieki nad nimi, ale nie pisano o znęcaniu się nad własnym ulubieńcem, wyrzuceniu z domu czy choćby zaniedbywaniu. Takie relacje były sporadycznie, głównie dzieci, znacznie bardziej szczerych.

Artykuł został oparty na szerokiej kwerendzie źródłowej. Wykorzystano 120 tytułów czasopism z lat 1918-1939. Nie było wprawdzie żadnego czasopisma poświęconego kotom - zapowiadano jego wydawanie, ale nigdy do tego nie doszło - istniały jednak pisma zajmujace się tematyką zwierzęca, w których można znaleźć, dosyć sporadyczne, informacje o kotach. Jako pierwsze można tu wymienić czasopismo „Mój Pies”, wychodzące w latach 1932-1939, a poświęcone głównie hodowli zwierząt rasowych. W latach 1929-1935 wychodził miesięcznik „Świat Zwierzęcy”, organ Polskiej Ligi Przyjaciół Zwierząt, koncentrujący się głównie na kwestiach organizacyjnych, chorobach zwierząt, a przede wszystkim walce z okrucieństwem: „Podkreślamy z całym naciskiem, że nieubłaganą walkę staczamy i nadal prowadzić będziemy z tymi, 
którzy w sposób okrutny obchodzą się ze zwierzętami”" . Sporo informacji można znaleźć w bardziej popularnym „Przyjacielu Zwierząt”, piśmie Towarzystwa Opieki nad Zwierzętami wydawanym w latach 1926-1931, którego następcą był „Świat i Przyjaciel Zwierząt”, organ Zjednoczenia Towarzystw Opieki nad Zwierzętami, ale zachowały się tylko pojedyncze jego numery z lat 1937-1938. W dodatku pisma te publikowały przede wszystkim zalecenia, mniej uwagi poświęcając opisowi rzeczywistości. Pojawia się ona między wierszami, w artykułach krytykujących niewłaściwe zachowania, w hasłach reklamowych, w ogłoszeniach, których treść czasem zaprzecza postulatom zawartym w artykułach.

Należy zatem sięgnąć również do czasopism niefachowych, w których znajdujemy wzmianki o kotach, zazwyczaj w tonie sensacyjnym, ale pokazujące pewne zachowania. Zostały one dobrane tak, aby reprezentowały wszystkie rejony Polski, były przeznaczone dla różnorodnych odbiorców - wielkomiejskiej inteligencji, mieszkańców małych miasteczek, gospodarzy wiejskich, dla kobiet i mężczyzn, dla dzieci i młodzieży, dla Polaków i Żydów. Są to zarówno popularne dzienniki, takie jak „Ilustrowany Kurier Codzienny”, „Czas” czy „Nasz Dziennik”, jak i miesięczniki, czasopisma naukowe i z poradami. Jak zauważył Karel Čapek i to właśnie biorąc koty za przykład - „Jeśli już mowa o kocich tematach dla gazet, zapytać należy: czy przeczytamy w jakimś piśmie o tym, że jakiś kot pożarł skowronka, albo urodził troje kociąt? Nigdy! Często natomiast spotykamy kota w koszmarnych okolicznościach, jak na przykład: wściekły kot pogryzł listonosza [...] urodził się kot o dziewięciu ogonach itp." ${ }^{5}$ Po lekturze czasopism nietrudno stwierdzić, że pisarz miał rację.

Ukazywało się sporo wydawnictw książkowych poświęconych zwierzętom, ale wśród nich zaledwie dwie pozycje dotyczą kotów. Książka Kot domowy. Jego rasy $i$ hodowla autorstwa Maurycego Trybulskiego ${ }^{6}$ poświęcona jest $\mathrm{w}$ głównej mierze zagadnieniom hodowlanym ${ }^{7}$. W serii „Życie praktyczne” wydawnictwa „Bluszcz” ukazała się też książka Pies $i$ kot, popularny poradnik dla właścicieli. Informacje o hodowli kotów można znaleźć także w dosyć nieoczekiwanych miejscach, jak w książce dla nowożeńców czy dziełach o zjawiskach paranormalnych.

${ }^{4}$ Prezes Zarządu P.L.P.Z. Romuald Mandelski, Drodzy Czytelnicy!, „Świat Zwierzęcy” 1929, nr 1 , s. 3.

${ }^{5}$ K. Čapek, Niezwykty świat gazety, „Chwila” 7 I 1934, s. 10.

${ }_{6}^{6}$ M. Trybulski, Kot domowy. Jego rasy $i$ hodowla, Warszawa 1935.

7 Na pewno książki o kotach ukazywały się w innych krajach. „Rewja Ilustrowana” zamieściła obszerna recenzję z pracy R. i E. Schumacher wydanej w Zurychu; A.M., Ksiqżka o kotach. Wojna trojańska w kocim spoteczeństwie, „Rewja Ilustrowana”, dod. do „Głosu Porannego”, 16 IV 1939, s. 9. 
Brak też cezur, które dla historyka są najważniejszym elementem porządkującym. Wojny, przewroty, zmiany władzy niekoniecznie muszą odbić się na stosunku społeczeństwa do kotów. Większe znaczenie choć $\mathrm{w}$ przypadku tak tanich w utrzymaniu zwierząt też niezbyt wielkie - ma stan gospodarki. W latach skrajnej biedy nie trzyma się zwierząt niepożytecznych, jednak taka sytuacja dotyczy raczej lat wojny czy głodu, przy mniejszych kryzysach kot nie był szczególnym obciążeniem.

Jedyna zatem cezura, jak się wydaje dosyć istotna, był rok 1928, gdy wprowadzono prawo o ochronie zwierząt.

\section{Przepisy i instytucje}

Przepisy dotyczace ochrony zwierząt były w latach międzywojennych stosunkowo nowym wynalazkiem ${ }^{8}$. Pierwsze ogłoszono w Anglii w $1822 \mathrm{r}$. z inicjatywy Richarda Martina9 ${ }^{9}$. W Polsce po odzyskaniu niepodległości obowiązywały w tym zakresie przepisy państw zaborczych. Większość dotyczyła polowań, rybołówstwa, badania zwierząt rzeźnych czy walki z chorobami zakaźnymi, czyli z punktu widzenia sytuacji kotów były niezbyt istotne, z wyjątkiem przepisów o zwalczaniu wścieklizny.

Najważniejsze rozporządzenie zostało wydane w 1928 r. ${ }^{10}$ Dotyczyło ochrony zwierząt i kar za znęcanie się nad nimi. Znęcanie się uznane zostało za wykroczenie, nie przestępstwo, zagrożone 6 tygodniami aresztu i grzywna (maksymalna grzywna wynosiła 2 tys. zł, czyli była bardzo wysoka). Za znęcanie się ze szczególnym okrucieństwem groziło do roku więzienia. Traktowanie zwierzęcia przestało być odtąd prywatną sprawą właściciela.

W Polsce nie istniały żadne przepisy legislacyjne dotyczące wyłącznie kotów, były one jednak wydawane w innych krajach europejskich i zapoznawano z nimi polskich czytelników. I tak np. w Austrii wydano

${ }^{8}$ Nie oznacza to, że przed tym okresem prawo nie zajmowało się zabijaniem czy okaleczaniem zwierzęcia, ale przede wszystkim na względzie miano kwestię uszkodzenia czy zniszczenia cudzej własności, a nie cierpienie zwierząt; zob. np. A. Perenc, Historia lecznictwa zwierzat $w$ Polsce, oprac. i uzup. K. Millak, wyd. 2, Wrocław-Warszawa 1958, rozdz. X: Weterynaria sqdowa, s. 382-397.

9 M.Z. Felsmann, J. Szarek, E. Strzyżewska, M. Lisiowska, I.M. Kowalski, Ochrona zwierzat w prawodawstwie polskim od 1918 do 1939 r., w: Dawna medycyna $i$ weterynaria. Środowisko a zwierze, red. M.Z. Felsmann, J. Szarek, M. Felsmann, Chełmno 2013, s. 75-76.

${ }_{10}$ Rozporządzenie Prezydenta Rzeczypospolitej z dnia 22 marca 1928 r. o ochronie zwierząt, Dz. U. 1932, nr 42, poz. 417, art. 4 i 5, http://dziennikustaw.gov.pl/ $\mathrm{du} / 1928 / \mathrm{s} / 36 / 332 / 1$. 
w 1930 r. rozporządzenie, „mocą którego używanie kotów do wypróbowywania wartości wyżłów uznane zostało za okrucieństwo i ma być surowo karane"11.

\section{W domu i poza nim}

Koty - nie te dzikie, ale ulubieńcy domowi - były w pewnym sensie niewidzialne, ich posiadanie nie było ani społecznie istotne, ani kontrolowane. Niemniej było popularne we wszystkich grupach ludności. W 1927 r. „Kurjer Poznański” stwierdzał, że koty są najliczniejszą grupą domowych pupili ${ }^{12}$. „ABC” w 1928 r. pisał o rosnacej liczbie kotów domowych. Miałoby to być skutkiem opodatkowania posiadania psów, a braku podatku od kota ${ }^{13}$.

Koty zazwyczaj bywały zwykłymi dachowcami. Rozdawano je za darmo, bo wychodzace kotki miewały mioty nawet co pół roku. Brano je z ulicy, otwierano drzwi przed przybłędami. Koty rasowe, kupowane w sklepach lub z ogłoszeń prasowych, były raczej rzadkie. Hodowla kotów rasowych dopiero się rozwijała. Koty rasowe trzymane były w domach, ale ras, jak się wydaje, było niewiele. Najczęściej były to koty angorskie i w latach trzydziestych syjamskie ${ }^{14}$, czasem, ale rzadko, pojawiają się persy i to dopiero od lat trzydziestych. Oprócz tego sporadycznie pojawiaja się koty syberyjskie, o ile nie liczyć ogłoszeń o futrach $\mathrm{z}$ tych kotów. Trudno jednak - w przeciwieństwie do psów - spotkać rzeczowy opis ras kotów. Nie ma ich nawet w specjalistycznych czasopismach, przy czym wiele wskazuje na to, że nie orientowano się powszechnie ani jak wyglądaja, ani jak się zachowują - może $\mathrm{z}$ wyjątkiem kotów angorskich, najpopularniejszej z ras. Najlepszym dowodem jest to, że koty rasowe były eksponatami w ogrodach zoologicznych. Nawet jednak ich dyrektorzy nie zawsze wiedzieli, jak wygląda rasowy kot. Wileńska gazeta donosiła w 1935 r.: „Do zwierzyńca przy ul. Mickiewicza 55 przybył pewien osobnik, który kierownikowi menażerji zaproponował nabycie pięknego syberyjskiego kota. Osobnik ów zaznaczył, iż podobny okaz został przed kilku dniami nabyty przez zwierzyniec

${ }_{11}$ Echa. Ochrona kotów w Austrii, „Świat Zwierzęcy” 1931, nr 2-3, s. 23.

${ }^{12} \mathrm{Kr}$, Nie całuj psa w nos! - Niebezpieczne pieszczoty - ostrożnie z matpami!, „Kurjer Poznański”, 8 IV 1927, s. 2.

${ }^{13}$ Kłopot $z$ 'maciusiami'. Warszawie grozi kocie przeludnienie, „ABC”, 28 VII 1928, s. 2 .

${ }^{14}$ Ogłoszenia o sprzedaży kotów syjamskich pojawiają się już w 1926 r., ale są jeszcze wówczas nieliczne. 
warszawski i te gatunki kotów w ogóle sa już na wymarciu i są rzadkimi okazami. Kierownik zwierzyńca nabył kota, przyczem nowy nabytek został umieszczony w klatce. W dniu wczorajszym, podczas oglądania zwierząt w zwierzyńcu jedna z pań [...] poznała skradzionego jej przed kliku dniami kota "Angora"15. Innymi słowy, nawet kierownik zwierzyńca w dużym mieście nie widział nigdy na oczy kota angorskiego.

Nie da się odtworzyć tego, do kogo głównie należały domowe koty ani w jakich domach najczęściej były trzymane, znaleźć je bowiem można było we wszystkich miejscowościach i wszystkich warstwach społecznych, w rodzinach biednych i bogatych ${ }^{16}$. Zazwyczaj opisywano domy, w których był jeden lub dwa koty. Większa liczba wywoływała zdziwienie, a często nadmierna liczba kotów budziła podejrzenia co do zdrowia psychicznego właścicieli.

Niewiele informacji mamy o życiu kotów wiejskich. Niewątpliwie jednak ich położenie i traktowanie było zupełnie inne niż w mieście. Były w większym stopniu zwierzętami gospodarskimi niż domowymi ulubieńcami. Trzymane były jako ochrona przed szkodnikami, a gdy przestawały być potrzebne pozbywano się ich z domu - nie było wiec mowy o przywiązaniu do zwierzęcia: „trzymane sa po chatach przez zimę dla obrony przed myszami, a gdy wiosna przyjdzie, nikt ich nie karmi, nikt ich nie pilnuje. To też włóczą się wszędzie, tropią i niszcza w ogromnej ilości nie tyle myszy, co właściwie ptactwo drobne"17. Fakt, że na wsi kotów nie karmiono, potwierdza inny artykuł: „U nas zwykle kotów nie karmia, włóczą się one i tępią drobne ptactwo" 18 .

Nie da się ustalić ani jak koty domowe były traktowane - co jest oczywiste, bo zapewne różnorodnie - ani nawet tego, jaka była obowiązująca norma ich traktowania. W pismach dla miłośników zwierząt można znaleźć wytyczne i porady dla właścicieli psów, ale nie sposób znaleźć analogicznych tekstów o kotach. Ich los nie wzbudzał takich emocji jak dola psów.

Istniał powszechny stereotyp, że to kobiety są zainteresowane kotami, to one żywią do nich jakieś uczucia (uznawane powszechnie za dość śmieszne), natomiast chłopcy i mężczyźni wybierają psy. Nie znajduje to chyba odbicia w rzeczywistości, zaskakująco często bowiem prasa

15 Rozpoznała swego kota „Angora” w zwierzyńcu, „Gazeta Wileńska” (wieczorna), 10 II 1935, s. 4.

${ }^{16}$ Można o tym wnosić choćby $\mathrm{z}$ artykułu dotyczącego skutków wprowadzenia podatku od posiadania kota; ELPE., Refleksje dnia. Opodatkowanie kotów, „Dziennik Poznański", 3 III 1931, s. 6.

17 K. Kulwieć, Brońmy i chrońmy ptaki, „Gazeta Świąteczna” 1931, nr 2619, s. 2.

18 J. Warmachowski, Ochraniajmy ptaki, „Nasz Przyjaciel” 1931, nr 19-20, s. 11. 
publikowała wywiady czy reportaże o znanych politykach, aktorach, sportowcach, którzy mieli swego ukochanego kota. Co może zaskakiwać - koty mieszkające w domu nie zawsze były własnością rodziny, a dosyć często do domu przynosiła je służąca. Nawet jednak, gdy kot należał do rodziny gospodarzy, nie zawsze dorośli w ogóle byli zainteresowani jego obecnościa, nie dbali o jego wyżywienie ani nie interesowało ich jego zdrowie czy dalszy los. Kot był bowiem tylko zabawka dziecka i tak go właśnie traktowano. Gdy dorośli - rodzice, a czasem nawet służące - dochodzili do wniosku, że kot przeszkadza, szkodzi - po prostu go wyrzucali. Z niektórych relacji w „Małym Przeglądzie” można także wnosić, że dzieci czasem same wyrzucały kota, który się znudził. Gdy ich ulubieniec był chory, dorośli nie zwracali na to uwagi, pozostawiając dziecku troskę o rannego czy umierającego kota.

Koty, w większym stopniu niż psy, nie były też brane „na zawsze”. Wyjazd $\mathrm{z}$ domu, zmiana mieszkania, wzięcie nowego zwierzęcia - to wszystko powodowało, że kot był oddawany, wyrzucany na ulicę albo zostawiany w poprzednim miejscu zamieszkania. Szczególnie to ostatnie zjawisko było częste i nie wynikało tylko z braku troski o zwierzę. Uważano bowiem, że kot przywiązuje się do miejsca, nie do ludzi, a więc przeprowadzka będzie dla niego gorsza niż pozostawienie na znanym mu podwórku czy ulicy. W ten sposób rosła liczba kotów bezdomnych, niepotrafiących już sobie poradzić na swobodzie. W żartobliwym felietonie dzielącym koty na pracujace i uprzywilejowane (czyli domowe) autor pisał: „Nie robią nic absolutnie, zawdzięczają swoje powodzenie dobrym manierom i pełnej godności postawie. [...] Grozi im jednak zawsze przeprowadzka państwa. Kiedy państwo się wyprowadzi i wprowadzi inne państwo, wówczas kot traci głowę, orientację, wałęsa się czas jakiś bez celu, wreszcie stacza się do rzędu kotów pośredników, dostaje ścierką przez łeb i poczyna spoglądać łakomie na wróble"19.

Trudno powiedzieć coś o przestrzeni zajmowanej przez koty w domu. $\mathrm{Z}$ relacji dzieci wiemy, że często spały w łóżku razem z nimi. Dorośli także przyznawali się do spania z kotem, więcej nawet - uznawano, że kotu spanie z ludźmi się należy, bo „pewnego razu, gdy do późnej nocy nie wracałem do domu kotka siedziała na moim łóżku i piszczała dotąd, dopóki nie obudziła brata, i nie wziął jej do swojego łóżka" ${ }^{20}$. Maurycy Trybulski stwierdzał, że kotki najchętniej rodzą na łóżkach albo w szafach, oba te miejsca można więc uznać za dobrze znane i uznane za przyjazne ${ }^{21}$.

\footnotetext{
19 Jur., Marcowe refleksje, „ABC”, 27 III 1935, s. 8.

20 Tamże.

${ }^{21}$ M. Trybulski, dz. cyt.
} 
W wielu relacjach pojawiał się wiejski kot leżący na przypiecku albo wylegujący się na schodach czy werandzie. W wielu domach najwyraźniej nie miał ograniczanego terytorium, może z wyjątkiem kuchni, skąd wypędzały go służące. Bywało jednak i tak, że kot mieszkał w kuchni i rzadko przynoszono go „na pokoje”. Koty na kanapach, fotelach, krzesłach (i pod nimi), a nawet koty chodzące po stole występują w opisach. Czyli dzieliły przestrzeń z ludźmi i nie trzymano ich w zamknięciu.

Nie wiemy nawet, czym prócz mleka karmiono koty. Na wsi raczej pozostawiano kotom troskę o własne wyżywienie. W mieście specjaliści radzili, by karmić je mięsem, szczególnie wołowina. Zalecano ryby, jarzyny gotowane wymieszane z mięsem, mlekiem lub jajkiem, a szczególnie szparagi ${ }^{22}$, bardzo przez koty lubiane i pobudzające apetyt. Jedzenie powinno być podawane w czystych miseczkach, różnorodne, zgodne z gustem wybrednego kota ${ }^{23}$. Można jednak sądzić, że powszechnie kierowano się jedną rada - to znaczy pozostawiano kotu miseczkę czystej wody, natomiast przeciętni właściciele kotów raczej nie mogli korzystać $\mathrm{z}$ rad karmienia kota befsztykiem ze szparagami.

Koty domowe wypróżniały się do specjalnego blaszanego naczynia, polecano piasek lub trociny. Opis wskazuje, że był to nowy obyczaj ${ }^{24}$, świadczący o tym, że wzrastała liczba kotów niewychodzacych. Początkowo właściwie nie spotyka się kotów niewychodzących, poza rasowymi, przeznaczonymi do hodowli. Na ogół uważano, że zamykanie kotów w obrębie ciasnego mieszkania to objaw niezrozumienia ich natury, a w wypadku kotek uniemożliwienie im przeżywania macierzyństwa, które miało być ich największą radością. Jedynym argumentem na rzecz niewypuszczania kotów było zagrożenie dla ptaków ${ }^{25}$. Wprawdzie koty bardzo często nie wracały, ale uważano, że ich bezpieczeństwo nie jest tak istotne jak wolność.

\section{Koty użytkowe}

Koty to nie tylko zwierzęta domowe, ale również zwierzęta użytkowe, podlegające tępieniu. Jednak bardzo często spotyka się opinie, że trzymanie kota jest bezsensowne, jest to bowiem zwierzę, z którego nie

${ }^{22}$ Wszystko wskazuje na to, że niektóre koty naprawdę karmiono szparagami. Autor artykułu wspomina, że jego kotka lubiła fasolę, kartofle, kalafiory, a także szparagi; C.Z., Uwagi o chara[k]terze kotów, „Przyjaciel Zwierząt” 1928, nr 2, s. 5.

${ }^{23}$ M. Trybulski, dz. cyt., s. 71-74.

${ }_{24}$ Tamże, s. 22, 67-68.

25 J. Białasz, Wróble, „Świat Zwierzęcy” 1931, nr 2-3, s. 21. 
ma żadnego pożytku. Autor użalajacy się nad losem pracujących koni, stwierdzał jednocześnie: „Kot, darmozjad, jest przedmiotem niezasłużonych pieszczot”" ${ }^{26}$. Miał w tym trochę racji. Choć powszechnie uznaje się, że koty są pożyteczne, strzegąc domów czy magazynów przed gryzoniami, to coraz rzadziej występowały w tej roli. Produkcja trucizn przeciw myszom i szczurom spowodowała, że coraz więcej fachowych czasopism, także przeznaczonych dla wsi, odradzało trzymanie kota $\mathrm{w}$ tym celu. Podkreślano też, że koty, poza wyselekcjonowanymi rasami, sa niezdatne do tępienia szczurów.

Nie przeszkadzało to jednak trzymaniu kotów w tym celu nie tylko w domach prywatnych, ale i w magazynach, na pocztach i okrętach.

Znacznie mniej znana jest inna rola kotów, jako pomocników w armii w czasie I wojny światowej. W tym wypadku służyły nie na ziemiach polskich, ale w Wielkiej Brytanii. Tam pół miliona kotów pełniło służbę podczas Wielkiej Wojny. Używano ich do wczesnego wykrywania gazów bojowych.

Nie należy też zapominać o hodowli kotów na potrzeby przemysłu futrzarskiego i wykorzystywania skórek kocich jako produktu leczniczego $^{27}$. Najlepszym dowodem na to, jak istotne było wykorzystywanie kocich futer jest fakt, że jedyna książka o hodowli kotów została wydana przez Związek Hodowców Zwierząt Futerkowych w Polsce ${ }^{28}$. Autor książki, prezes Związku Maurycy Trybulski, wyrażał ubolewanie, że w Polsce rozwijają się prężnie hodowle zwierząt futerkowych takich jak lisy, norki itd., tymczasem raczej nie tworzy się hodowli kotów z przeznaczeniem na futra ${ }^{29}$. Zachęcał: „Istnieją też hodowle kotów na futerka, które moga być rentowne tylko w tych wypadkach, gdy się chowa koty, których futerko imituje futra cennych zwierząt [...]. Oczywiście muszą być tu brane pod uwagę koszty produkcji, które zazwyczaj są dosyć wysokie"30. Trudno powstrzymać się od uwagi, że biorąc pod uwagę zalecane przez tegoż autora karmienie kotów śmietana, befsztykami i szparagami, skórki cennych zwierząt musiały wypadać taniej ${ }^{31}$.

${ }^{26}$ K. Szuman, O niedoli koni roboczych, „Przyjaciel Zwierząt” 1928, nr 7, s. 6.

27 „Czas”, 15 V 1919, s. 4.

${ }_{28}$ M. Trybulski, dz. cyt.

29 Tamże, s. 7.

30 Tamże, s. 83.

${ }^{31}$ Warto przytoczyć tu reklamę kocich futer: „Futro kocie jest podobno jednym z najpiękniejszych. Posiada jednak wadę, a mianowicie ogromną rozmaitość kolorów, która utrudnia dobranie całości”; Kocie futra, „Kurjer Poznański”, 10 XI 1927, s. 2. Co interesujące, identyczne notatki ukazały się w bardzo różnych pismach - w żydowskim dzienniku lwowskim „Chwila”, 14 XI 1927, s. 7, czy w „Ziemi Lubelskiej”, 11 XI 1927, s. 2. 
O ile futra kotów rasowych (głównie syberyjskich) albo futra stylizowane na lepsze gatunki sprzedawano w sklepach futrzarskich, nawet luksusowych, o tyle byle jak wyprawione kocie futerko było synonimem biedy, nie luksusu. „Robotnik” tak opisuje dziewczynę z biednej dzielnicy, która chciała się wystroić na Wielkanoc: „Co chwilę poprawia szmat futerka z kota, czy ze szczura, majacego ogrzewać jej plecy i zdobić figurę" ${ }^{32}$. Futra z kotów były modne w latach dwudziestych i wróciły do łask pod koniec następnej dekady.

\section{Groźne zwierzęta}

Koty w kulturze europejskiej zawsze były zwierzętami niebezpiecznymi albo przynajmniej podejrzanymi. W średniowieczu przedstawiane były czasem jako wcielenie szatana. Czarne koty uważano za przynoszace pecha, były atrybutem czarownic, a w czasach późniejszych występowały jako nieodłaczni towarzysze osób parających się przepowiadaniem przyszłości. Choć oczywiście w okresie międzywojennym nie uważano już kota za wcielenie diabła, to jednak nieufność do tych zwierząt pozostała i w omawianym okresie była bardzo widoczna. Dzisiejsza wizja kotów jako słodkich, puchatych stworzeń była obca mieszkańcom II RP. Koty czasem kochano, ale równie często się ich obawiano - i to z bardzo różnych przyczyn.

Niewątpliwie najbardziej racjonalny był lęk przed przenoszeniem chorób, w tym przede wszystkim wścieklizny. Pogryzienia przez wściekłe koty nie były bardzo częste, ale dochodziło do nich wcale nierzadko. Mimo to nie wydaje się, aby na co dzień ludzie obawiali się dziko żyjących kotów. Nawet przestrzegajacca przed wścieklizna prasa podawała zazwyczaj objawy tej choroby u psa, o kotach wspominając tylko sporadycznie.

Obawiano się natomiast, że kot może zrobić krzywdę małemu dziecku. Choć fachowa prasa nie ostrzegała przed takim niebezpieczeństwem trzymania kota $\mathrm{w}$ domu, to pisma codzienne i to zarówno popularne, jak i przeznaczone dla wyrobionych czytelników, podawały zaskakująco często informacje o morderczych zachowaniach kotów. W Łodzi „w nocy żona robotnika usłyszała cichy jęk dziecka. Gdy zapalono światło, ujrzano straszną scenę. Kot siedział koło maleństwa obejmując je łapami. Okazało się, że dziecko miało przegryzioną szyję i dawało już słabe oznaki życia. Przed przybyciem lekarza dziecię zmarło"33. Koty

\footnotetext{
${ }^{32}$ Zysław, Mały felieton. Tłum świateczny, „Robotnik”, 8 IV 1920, s. 2.

${ }^{33}$ Drobne wiadomości. Kot zagryzt dziecko, „Gazeta Kartuska”, 20 XII 1930, s. 3.
} 
raczej jednak nie zagryzały swoich małych ofiar, a dusiły je. „Bestia kot swym ciężarem zadusił małą Stasię" ${ }^{34}$. Problem w tym, że w rzeczywistości koty nie zagryzają ani nie duszą niemowląt, a tym bardziej starszych dzieci. Wydaje się zatem, że na kota, istotę uznawaną za nieczuła i groźna, zrzucano winę $\mathrm{w}$ wypadku niewyjaśnionej śmierci dziecka, a być może także w wypadku zbrodni. Tak czy inaczej głęboko wierzono, że kot może zabić dziecko i w ten przesą niektórzy wierzą jeszcze dziś.

I wreszcie pożary. Tu rzeczywiście kot był czasem sprawcą nieszczęścia. Przebieg wydarzeń zawsze był taki sam - zapalenie się sierści od otwartego źródła ognia, następnie płonący kot w panice obiegał gospodarstwo, podpalając wszystko po drodze ${ }^{35}$. Takie wypadki zdarzały się na wsiach i w małych miastach, gdzie nadal używano otwartych źródeł ognia do ogrzewania i oświetlania. Za to w większych miastach od lat trzydziestych koty odkręcały zawory gazu i powodowały śmierć całej rodziny $^{36}$. O ile pożary rzeczywiście bywały wzniecane przez koty - tak powszechnie, że stały się alibi dla podpalaczy, o czym wspomina nawet instrukcja dla straży pożarnej: „Zdarza się, że podpalacz obwinia kota jako przyczynę pożaru, któremu przypali grzbiet” ${ }^{37}$, to należy jednak sądzić, że przypadki odkręcenia gazu mogły być tylko przeniesieniem „wiejskiego" niebezpieczeństwa w realia miejskie. Kot bowiem był potencjalnie niebezpiecznym stworzeniem i tak go postrzegano, niezależnie od miejsca zamieszkania.

\section{Od „rzeczy” do ,istoty”}

Przemiany w stosunku do zwierząt można najlepiej prześledzić, analizując informacje o okrucieństwie wobec zwierząt i sposobach zapobiegania temu zjawisku i karania winnych. Trudność polega na tym, że to, co uznawano za znęcanie się nad zwierzęciem, a co nie, było w okresie II Rzeczypospolitej zmienne w czasie, zależało od środowiska i gatunku zwierzęcia. Szczególnie sposoby zapobiegania czy też karanie sprawców było częściowo pochodną zmieniającego się prawa. Sądząc z relacji prasowych, stopniowo prawo z 1928 r. wpływało też na obyczaje. Oczywiście

${ }^{34}$ Kot udusit dziecko, „Gazeta Kartuska”, 9 I 1937, s. 1.

${ }_{35}$ Zob. m.in. Matka z trojgiem dzieci ginie $w$ ptomieniach. Groźny pożar w woj. sieradzkim, „Nowy Dziennik”, 27 I 1934, s. 11; Kot przyczyna zatrucia się 20-letniej dziewczyny, „Nasz Przegląd”, 6 II 1927.

${ }_{36}$ Zob. m.in. Koty spowodowaty śmierć dwuch [sic!] staruszek, „5-ta Rano”, 25 I 1932, s. 2.

${ }^{37}$ Instrukcja o zwalczaniu zbrodniczych podpalen, Poznań 1932, s. 30. 
znacznie więcej uwagi poświęcano bardziej szanowanym gatunkom, albo raczej może tym, które były bardziej widoczne, ponieważ pojawiały się na targowiskach. „Stwierdzić należy, że największy procent przestępstw przypada na nadużycia nad końmi, następnie nad drobiem, ptactwem śpiewającym, wreszcie nad kotami i psami" ${ }^{8}$ - konstatowano w sprawozdaniu Ligi Ochrony Zwierząt za rok 1934. Wydaje się jednak, że nie tyle przestępstw było więcej, ile w większym stopniu były one dostrzegane przez inspektorów Ligi. Nad kotami i psami znęcano się w zaciszu domowym, poza zasięgiem czujnych oczu inspektorów.

Nie będą interesowały nas tu poszczególne przypadki okrucieństwa, których było bardzo dużo, ale ewolucja postrzegania tego, co jest, a co nie jest znęcaniem się nad zwierzęciem.

W pierwszych latach II Rzeczypospolitej dręczenie kotów, szczególnie na wsiach i przez młodzież, uznawane było za niepożądana, głupia, ale jednak rozrywkę. Nie oburzano się, że młodzi chłopcy urządzali polowanie na kota sasiadów, do prasy trafiało to tylko wówczas, gdy zamiast kota postrzelony został kolega ${ }^{39}$. Strzelanie do kotów w mieście, a szczególnie na letniskach, było prawdziwą plaga ${ }^{40}$, ale problemem nie było zabijanie kotów, lecz bezpieczeństwo przechodniów. Także wiele innych przypadków, które dziś ocenilibyśmy jako znęcanie się nad kotem, traktowano jako dopuszczalną zabawę. Wrzucanie w środek zbiegowiska, aby wywołać panikę, przywiązywanie puszek do ogona itd. nie budziło szczególnego poruszenia. Tymczasem w przypadku psów wrażliwość społeczna rosła szybko. Nie tylko bicie czy zbyt krótkie łańcuchy zaczynały być potępiane, ale nawet przepis nakazujący wyprowadzanie psów na smyczy i w kagańcach - jako przykład podawano Belgię, w której takich zaleceń nie ma, a psy nie gryza, są bowiem troskliwie pielęgnowane i nie doznają krzywd ${ }^{41}$.

Na koty polowano. Strzelano do nich nie tylko przypadkowo, a wśród zdobyczy łowieckich oprócz saren, dzików czy zajęcy wymieniano także koty. Choć strzelanie do kotów nie było zabronione, to coraz częściej budziło oburzenie. „Mój Pies” donosił w 1938 r. o ulotce wydanej przez powiatową radę łowiecką w Grodnie: „Kto dostarczy nos dorosłego psa lub nos dorosłego kota, otrzyma nagrodę w wysokości 50 gr.”; „Nosy te

38 Sprawozdanie za rok 1934 złożone przez Zarzad Ligi Ochrony Zwierzat na walnem zebraniu z dn. 10 maja 1935 r., „Świat Zwierzęcy” 1935, nr 1, s. 18.

${ }^{39}$ (K.), Tragiczne polowanie. Zapaleni mtodzi Nemrodzi - Łowy na kota - Fatalny strzat, „Kurjer Poznański”, 28 XI 1925, s. 3.

${ }^{40}$ Wróble, brauning $i$ osty (Z letnisk podmiejskich), „Kurjer Warszawski”, 12 VII 1925, s. $12-13$.

${ }^{41}$ Ettiene, Belgia - rajem dla piesków, „Mój Pies” 1934, nr 3, s. 9-10. 
[...] mają być nadziane na kółka druciane"42. Zareagował Zwiąek Stowarzyszeń Opieki nad Zwierzętami i oświadczył, ze tego typu działalność lokalnych stowarzyszeń łowieckich będzie zwalczał i że jest to publiczne zachęcanie do przestępstwa. Codzienne czasopisma przedrukowywały tę informację i wszędzie ulotka spotykała się z niesmakiem lub potępieniem.

O szczególne okrucieństwo oskarżano przede wszystkim młodych chłopców. W reportażu o kobiecie, która zajęła się bezdomnym kotem, któremu ktoś wyłupił oczy, pokazywane są dwie postawy. Kobiety handlujące na targowisku chwalą młoda dziewczynę za dobre serce i lituja się nad kotem. Inny jest jednak „stosunek całej gromady wyrostków, obserwujacych scenkę owego opatrunku nieszczęsnego kota. - To frajerka! [...] - A u nas w podwórku to kota zaraz za łapy na sznurek i hajda na drzewo! - Głupi jesteś, najlepiej to pakiem zalepić nos, zabawa wtenczas na całego!"43. Autor z przerażeniem słuchał tych rozmów, winiąc za zaniedbanie wychowania i rodziców, i szkołę.

Druga grupa to dozorcy domowi, którzy często pojawiali się jako oskarżeni w procesach o znęcanie się. Problem w tym, iż lokatorzy oczekiwali, że koty nie będą zanieczyszczać podwórka i klatek schodowych, stąd też pozbywano się kotów często barbarzyńskimi metodami.

Koty były bohaterami doniesień kryminalnych, zazwyczaj w roli ofiar. Istotny dla oceny wrażliwości społecznej był opis zbrodni dokonanej na wsi na Kielecczyźnie. Jest to istotne, reportaż pochodzi bowiem z 1925 r., a wiec przed wprowadzeniem prawa o ochronie zwierzat. Wymordowano wówczas całą rodzinę, a sprawcy żywcem przybili kota do ściany. Fakt okrutnego zabicia zwierzęcia oburzył reportera nie mniej, jeśli nie bardziej, od zemsty dokonanej przez bandytę na całej rodzinie ${ }^{44}$.

To, co przez wiele lat było zabawą czy też było uważane za dopuszczalne, ponieważ właściciel zwierzęcia mógł nim swobodnie rozporządzać, stopniowo przestawało takim być. Data graniczna był rok 1928. Stawiano wówczas za przykład Wielką Brytanię. „Kiedyż nasze sądy zajmą się dręczycielami zwierząt” - pytał reporter „Rzeczpospolitej” ${ }^{45}$. Gdy przykład już wzięto i polskie sądy zaczęły skazywać dręczycieli, Anglia nadal była wzorem, tam orzekano bowiem wyższe kary ${ }^{46}$.

${ }^{42} 50 \mathrm{gr}$. za nos psa lub kota. Jak się prześladuje zwierzęta w Grodnie, „Mój Pies” 1938, nr 12, s. 3 okładki.

${ }^{43}$ I. Raca, Złote serce, „Przyjaciel Zwierząt” 1930, nr 5-7, s. 6.

${ }^{44}$ Straszna zemsta bandyty, wymordowat matżonków, potem zwierzęta, a wreszcie kota żywcem przybił do ściany, „Ziemia Lubelska”, 13 X 1925, s. 3.

45 Bierzmy przyktad $z$ Anglii, „Rzeczpospolita”, 28 VIII 1925, s. 7.

${ }^{46}$ W Anglii niema [sic!] żartów z ludźmi, którzy męcza zwierzęta, „Świat i Przyjaciel Zwierząt” 1937, nr 3, s. 7. 
Już wcześniej opisywano pojedyncze przykłady karania sprawców znęcających się nad kotami. „Pełen zezwierzęcenia Czesław Majewski w dziki, bestialski sposób powykłuwał kotowi [sic!] oczy, myśląc, że ujdzie kary, bo kot był jego własnościa. Nie panie, nie wolno dręczyć zwierząt, choćby one były nawet twoją własnościa, toteż zupełnie słusznie zostałeś pociagnięty do odpowiedzialności”" ${ }^{47}$. Zatem także przed 1928 r. dostrzec można dwa rodzaje podejścia do zwierząt, stopniowo przestawały one być nie tylko w świadomości niektórych ludzi, ale i w rozumieniu prawa rzecza, własnościa, coraz częściej były uznawane za istoty podlegające ochronie.

Po 1928 r. ten drugi sposób widzenia zwierząt zaczął być obowiązujący, choć oczywiście prawdopodobnie w nieporównanie większym stopniu w prasie niż w życiu codziennym. Czasopisma piętnowały chłopców bijących koty, dozorców wyganiających je bestialsko z podwórka, osoby źle zajmujące się kotem - niedające mu jeść czy zamykające na długo w domu bez dostępu do żywności. Ale nadal wyrzucenie kota z domu czy zostawienie go na podwórku w czasie przeprowadzki było uważane za całkiem normalne, podobnie jak występy cyrkowe czy w reklamach.

Sprawcy przemocy coraz częściej stawali przed sądem. W kronice sądowej „ABC” w 1932 i 1934 r. omawiano sprawy, w których bohaterami były koty. Pierwsza z nich to historia właściciela, który chciał zdyscyplinować kota. „Doprowadzony do ostateczności pan Majer zastosował wobec krnąbrnego kota represje. Z dziennej racji żywności odjał mu smakowite mięsne odpadki, dając tylko kwaszoną kapustę. Wtedy kot poszedł w swych buntowniczych zapędach tak daleko, że przestał jeść. Pan Majer bił go, a kot nie je i nie je. Nie wiadomo, jakby skończyła się ta historia, gdyby nie interwencja, zgoła nieoczekiwana ze strony sąsiadek. Oskarżyły pana Majera przed policją i [...] sąd grodzki XI okręgu wlepił mu dwadzieścia złotych grzywny za znęcanie się nad zwierzętami" ${ }^{\prime \prime}$. Z wielu względów to interesująca notatka. Choć sprawa nie wydawała się reporterowi poważna, jednak poważna musiała wydać się osobom, które w obronie kota udały się na policję. Sąd uznał winę oskarżonego. Druga sprawa była bardziej skomplikowana. Chodziło o człowieka, który brał kotki na wychowanie, a potem traktował jako obiekty do ćwiczeń dla swego jamnika w duszeniu zwierzyny. Tu także sprawa została zgłoszona i doszło do rozprawy przed sądem ${ }^{49}$. To jeszcze

${ }^{47}$ Za znęcanie się nad zwierzęciem, „Ziemia Lubelska”, 15 VII 1925, s. 4.

48 Very, Przed kratkami. Krnabrny kot, „ABC”, 7 VII 1932, s. 4.

${ }^{49}$ Very, Przed kratkami. Dobre ręce, „ABC”, 20 VIII 1934, s. 6. 
bardziej interesujący przypadek, bo tego typu szkolenie psów myśliwskich nie było sprzeczne $\mathrm{z}$ prawem.

W zupełnie poważnym tonie w 1935 r. „Dzień Dobry” donosił o toczacej się sprawie. Mężczyzna zatłukł kota dragiem. Kot należał do sąsiadki, a oskarżony tłumaczył się „stanem nietrzeźwości”. Ważne było stwierdzenie, że oskarżony stanie przed sądem za dręczenie kota, a nie za to, że zabił kota należącego do kogoś innego. Sąd uznał zatem, że istotą sprawy nie jest zniszczenie cudzej własności, a znęcanie się nad żywą istota ${ }^{50}$. Koty stopniowo przestawały być „rzeczą, a zaczynały być „istota”, która ma prawo do obrony, niezależnie, czy do kogoś należy, czy nie.

Kary za znęcanie się nad kotami rosły. W felietonie z 1937 r. opisywano przebieg dramatycznego wydarzenia. „Kot sasiada Gajowniczka zakradał mu się do kurnika i wypijał jaja. Już ty więcej nie przyjdziesz pogadywał Hardy [...]. Przydeptał go potężnie butem [...], a koci ogon ścisną nadszczepanym łuczywem. [...] Nasyciwszy w ten sposób swoje uczucie zemsty puścił kota spod buta"51. Kot zaczepił łuczywem o sztachety, a próbując się uwolnić, oderwał sobie ogon. Wyrok zapadł wysoki jak na owe czasy - miesiąc aresztu za nieludzkie obchodzenie się ze zwierzęciem, 30 zł odszkodowania i 3,50 zł kosztów sądowych. Warto zwrócić uwagę, że wyrok zapadł nie za zabicie kota, ale za przywiązanie mu czegoś do ogona (bo przecież skutku śmiertelnego nie mógł sprawca przewidywać), czyli za coś, co jeszcze niewiele lat wcześniej uznawane było za całkiem normalną zabawę dzieci.

Ale przemiany zachodziły nie tylko w odniesieniu do okrucieństwa. Zaczęto uznawać, że nie tylko koty mające właścicieli powinny być chronione. Po I wojnie światowej zaczęto pisać o bezdomności kotów. To samo w sobie jest istotna konstatacja, oznacza bowiem, że uznano koty za zwierzęta typowo domowe, dla których życie na wolności nie jest stanem naturalnym. Takie postrzeganie kotów było nowościa, ponieważ koty tępiące gryzonie uważane były przez wieki za miejską faunę. Teraz zaczęto patrzeć na nie, podobnie jak na psy, jako na istoty, którym potrzebna jest opieka domowa: „nieludzkim jest traktowanie psów i kotów bezdomnych. Nikt głodnego nie nakarmi, ani zziębniętego nie ogrzeje, a każdy czuje się w prawie cisnąć w niego kamieniem" ${ }^{52}$. Z drugiej strony zagrożenie wścieklizna powodowało, że zwierzęta żyjące na ulicy uważano za potencjalnie niebezpieczne, a zatem były wyłapywane

${ }^{50}$ Zattukt kota przez zemstę za zjedzenie 2 kg schabu, „Dzień Dobry. Dziennik Ilustrowany", 14 III 1935, s. 9.

51 J. Szczapa, Ile kosztuje koci ogon?, „Gazeta Świąteczna” 1937, nr 2841, s. 5.

${ }^{52} Z$ życia organizacyj. Polska Liga Przyjaciół Zwierzat w roku 1931. Siedlce, „Świat Zwierzęcy” 1932, nr 4-5, s. 17. 
i likwidowane. W wielu miastach, w tym w Warszawie, istniał poważny problem z olbrzymia liczbą kotów żyjących na ulicach ${ }^{53}$.

Redakcja „Świata Zwierzęcego” ubolewała: „Nie ma dnia, żeby do naszego biura nie zgłoszono się z prośbą o przygarnięcie znalezionego psa lub kota, albo o tymczasowe pomieszczenie zwierzęcia podczas nieobecności właściciela" ${ }^{54}$.

Początkowo najistotniejszym problemem było pozbywanie się z ulic wałęsających się zwierząt. Zwierzęta bezpańskie wyłapywano i zabijano, o ile nie zgłosił się właściciel. Usypianie bezdomnych zwierząt było akceptowane, ale od końca lat dwudziestych coraz więcej osób nalegało, by robic to w sposób humanitarny. W „Świecie Zwierzęcym” z 1929 r. w rubryce „Ofiary” znajdujemy informacje o stosunkowo wysokich datkach: „Na chloroform dla usypiania zwierzat. Na humanitarne usypianie bezdomnych i nieuleczalnie chorych psów i kotów z gorąca prośba, aby dobrzy ludzie nie opuszczali w nieszczęściu najlepszych swoich przyjaciół G. K. M. - 24 zł”55. Podobne anonse można znaleźć w niemal każdym numerze.

W latach trzydziestych zaczęto przekonywać, że o ile rzeczywiście konieczne jest zmniejszenie liczby bezdomnych zwierząt na ulicach, o tyle ich zabijanie wcale konieczne już nie jest. W gazetach zaczęły pojawiać się wzmianki o schroniskach za granica, a na początku lat trzydziestych informacje o istnieniu schronisk także w Polsce. Oczywiście były one przede wszystkim przeznaczone dla psów. W sprawozdaniu TOZ z 1932 r. można przeczytać znamienny opis: „Przez Koło Schroniskowe przeszło ogółem w r. 1932247 psów [...]. 31 psów odzyskało swoich właścicieli [...]. Od nosówki padło 26 psów, uśpiono 15, padło ze starości 2 psy. Obecnie w schronisku znajduje opiekę 46 psów. Reszta psów została oddana w prywatne ręce, po uprzednim sprawdzeniu warunków bytowania psa. Koło posiada również koty. Obecnie znajduje się w Schronisku 36 kotów"56. Uderza różnica w opisie działalności dotyczącej psów i kotów - w przypadku psów podaje się choroby, liczbę zgonów, a także podejmowane działania, aby znaleźć zwierzętom dom. Koty pozostawały na marginesie zainteresowania, nawet działacze TOZ nie byli szczególnie przejęci ich losem. Liczba schronisk stale jednak rosła, a i coraz więcej z nich szukało domów także dla bezdomnych kotów.

${ }^{53}$ Koty nie musiały być koniecznie bezpańskie, ponieważ większość kotów była wychodząca i dużą część życia spędzała poza domem.

${ }^{54}$ Od Redakcji, „Świat Zwierzęcy” 1929, nr 4, s. 12.

55 Ofiary, „Świat Zwierzęcy” 1929, nr 7-8, s. 24.

${ }^{56}$ Komunikat Tow. Opieki nad Zwierzętami, Sprawozdanie za 1932 rok, „Mój Pies” 1932, nr 8-9, s. 20. 
Zmiany widać także w podejściu do chorób kotów. We wcześniejszych latach kotów raczej nie badano (poza podejrzeniami wścieklizny), a jeśli leczono, to domowymi sposobami. Nawet fachowe czasopisma radziły, co robić w wypadku złego samopoczucia kota, ale nie zalecały zwracania się do weterynarza i to nie tylko dlatego, że nie było do nich dostępu. Już przed $1918 \mathrm{r}$. istniała w Warszawie bezpłatna lecznica dla zwierząt, później tworzono je też w innych wielkich miastach. Jednak i tu da się zauważyć szybkie zmiany. Gdy w latach dwudziestych opisywano leczenie małych zwierząt za granica, zazwyczaj traktowano to jako fanaberie zamożnych właścicieli, którzy nie mają na co wydawać pieniędzy. W istniejacych lecznicach koty leczono zdecydowanie rzadziej niż psy. „Kurjer Wileński” z 1926 r. zamieścił sprawozdanie za rok 1925 z samorządowego ambulatorium dla zwierząt. Ambulatoryjnie leczono „psów 211, kotów 9"57. W 1927 r., w tym samym Wilnie, w lecznicy sejmikowej przyjęto 544 psów i 14 kotów ${ }^{58}$. Statystyki lecznicy TOZ podające liczbę zwierząt, którym udzielono pomocy, wskazuja, że w przybliżeniu pięciokrotnie częściej przychodzono na wizytę z psem niż kotem, a gdy płacono za poradę - 23-krotnie częściej, choć oczywiście trudno wyciagać wnioski z działalności kilku tylko lecznic ${ }^{59}$.

W latach trzydziestych opisy przychodni dla zwierząt są już pisane w zupełnie innym, poważnym tonie, autorzy reportaży wyrażają podziw dla lekarzy, a zwiększenie liczby lecznic jest uznawane za konieczne.

Jak widać, traktowanie kotów w okresie międzywojennym było bardzo zróżnicowane i równolegle funkcjonowały sprzeczne ze sobą normy. Akceptowane były i koty jako domowi ulubieńcy, i jako zwierzęta, które powinny zapracować na swoje utrzymanie, i jako zwierzęta hodowlane, z przeznaczeniem na futra. Wprawdzie widać, że coraz bardziej - przynajmniej wśród ludzi wykształconych - przejmowano się dolą kotów

${ }^{57}$ Kronika. Z działalności ambulatorium samorzqdowego dla zwierzqt za $1925 \mathrm{r}$., „Kurjer Wileński”, 25 II 1926, s. 4.

${ }_{58}$ Z posiedzenia Sejmiku Wileńsko-Trockiego, „Słowo”, 23 II 1927, s. 2.

${ }^{59}$ W sprawozdaniu za 1929 r. podawano, że pomocy udzielono w lecznicy TOZ 1030 psom i 241 kotom; Sprawozdanie Zarzadu T-wa Opieki nad Zwierzętami Rzplitej Polskiej za r. 1929, wygtoszone przez prezesa E. Kłossowskiego na Walnem Zgromadzeniu dnia 18 maja 1930 r., „Przyjaciel Zwierząt” 1930, nr 5-7, s. 3. Różnica jest tak duża, że można sądzić, iż przyczyną było nie tylko to, że u kotów trudniej zauważyć objawy choroby, a umierające koty kryją się przed ludźmi. Nie jest możliwe, aby w domach trzymano o tyle częściej psy niż koty, jest więc oczywiste, że kotami zajmowano się mniej troskliwie. 
i występowano w ich obronie, ale jednocześnie fakt dręczenia kotów przez dzieci był uważany za zjawisko całkowicie naturalne. Różnica pomiędzy latami dwudziestymi, gdy troska o zwierzę traktowana była, przynajmniej przez publicystów, jako fanaberia, a trzydziestymi, gdy uznawano ją już za obowiązek cywilizowanego społeczeństwa, jest wyraźnie zauważalna. Coraz częściej los zwierząt, w tym kotów, ich traktowanie przez ludzi stawało się tematem poruszanym w publicystyce. Zwraca też uwagę, że część zachowań uważanych niegdyś za folklor, za zachowania absolutnie normalne (topienie niechcianych miotów, wybijanie zwierząt $\mathrm{w}$ przypadku wścieklizny $\mathrm{w}$ okolicy) potępiano albo przynajmniej postulowano zmianę metod. $\mathrm{O}$ znęcaniu się nad zwierzętami donosili nie tylko ludzie wykształceni, ale sassiedzi czy np. przechodzący obok śmieciarz. Jest to więc okres przełomu - pomiędzy traktowaniem kotów (a szerzej - zwierząt) jako rzeczy, własności, z która wolno robić, co się chce, a uznaniem ich za żyjące istoty, indywidualności zasługujace na szacunek i dobre traktowanie. Oczywiście trzeba pamiętać, że mowa tu o publicystyce, która nie odwzorowuje wiernie życia społecznego. Nie ulega wątpliwości, że zmiany te zachodziły nie tyle $\mathrm{w}$ rzeczywistości, ile raczej w sposobie jej opisywania. Zwierząt nadal nie traktowano dobrze, ale z pewnością bardzo widocznie zmieniały się normy stosunku do nich. A to już jest zazwyczaj pierwszy krok do zmiany zachowań. Wojna, która nie sprzyja łagodzeniu obyczajów, a na pewno nie jest czasem, w którym istotna kwestia sa prawa zwierząt, przerwała na wiele lat stopniowe przechodzenie do lepszego ich traktowania, jako istot żyjących i czujacych.

\section{Bibliografia}

Baratay É., Zwierzęta w okopach. Zapomniane historie, tłum. B. Brzezicka, Gdańsk 2017.

Białasz J., Wróble, „Świat Zwierzęcy” 1931, nr 2-3, s. 21.

DeMello Margo, Animals and Society. An Introduction to Human-Animal Studies, New York 2012.

Felsmann M.Z., Szarek J., Strzyżewska E., Lisiowska M., Kowalski I.M., Ochrona zwierzat w prawodawstwie polskim od 1918 do 1939 r., w: Dawna medycyna i weterynaria. Środowisko a zwierze, red. M.Z. Felsmann, J. Szarek, M. Felsmann, Chełmno 2013, s. 75-93.

Konecki K.T., Ludzie i ich zwierzęta. Interakcjonistyczno-symboliczna analiza spotecznego świata właścicieli zwierzat domowych, Warszawa 2005.

Landau-Czajka A., Między bajka a rzeczywistościa. Kot w pisemkach dla dzieci w II Rzeczypospolitej, w: Kot w literaturze, kulturze, języku i mediach, 
red. E. Borkowska, A. Borkowski, M. Długołęcka-Pietrzak, S. Sobieraj, Siedlce 2018, s. 355-371.

Perenc A., Historia lecznictwa zwierzat $w$ Polsce, oprac. i uzup. K. Millak, wyd. 2, Wrocław-Warszawa 1958.

Anna Landau-Czajka

Cats in the society of the Second Polish Republic

(Summary)

The article presents the attitude towards cats - and more broadly to all animals - in the society of the Second Polish Republic, and seeks to answer the question of whether any considerable evolution in this aspect could be noticed within the twenty years of the state's existence. It discusses the living conditions of domestic cats, the issue of cruel treatment of these animals, their use as a resource (e.g. in the fur industry). It also answers the question of why so many people feared cats and considered them to be dangerous. The paper describes the changing norms in the treatment of animals from the 1920s, when owning a domestic pet was considered an idle fancy, to the 1930 s, when caring for animals became seen as a duty of a civilized society. The period marked a turning point in the attitudes towards cats and animals in general, from considering them property whose management remained fully at the discretion of the owners to seeing them as living creatures and individual beings who deserve respect and good treatment. Naturally, the analysis present in the article is based on publications which did not fully reflect the social life of the period. It is certain that the aforementioned changes were more visible in the descriptions of reality than in reality itself, but this usually marks the first step in behavioral changes within societies.

Anna Landau-Czajka - profesor Instytutu Historii im. Tadeusza Manteuffla Polskiej Akademii Nauk, członkini Komitetu Nauk Historycznych PAN. Autorka monografii: W jednym stali domu... Koncepcje rozwiazania kwestii żydowskiej w publicystyce polskiej lat 1933-1939, Warszawa 1998; Co Alicja odkrywa po wtasnej stronie lustra. Życie codzienne, społeczeństwo, władza w podręcznikach dla dzieci najmłodszych 1785-2000, Warszawa 2002; Syn będzie Lech... Asymilacja Żydów w Polsce międzywojennej, Warszawa 2006; Polska to nie oni. Polska i Polacy w polskojęzycznej prasie żydowskiej II Rzeczypospolitej, Warszawa 2015; Wielki „Maty Przeglad”. Społeczeństwo i życie codzienne w II Rzeczypospolitej w oczach korespondentów „Matego Przegladu”, Warszawa 2018. 
Anna Landau-Czajka - professor at the Tadeusz Manteuffel Institute of History of the Polish Academy of Sciences, member of the Committee of Historical Sciences of the Polish Academy of Sciences. Author of monographs: W jednym stali domu... Koncepcje rozwiazania kwestii żydowskiej w publicystyce polskiej lat 1933-1939, Warsaw, 1998; Co Alicja odkrywa po wtasnej stronie lustra. Życie codzienne, spoteczeństwo, władza $w$ podręcznikach dla dzieci najmłodszych 1785-2000, Warsaw, 2002, Syn będzie Lech... Asymilacja Żydów w Polsce międzywojennej, Warsaw, 2006; Polska to nie oni. Polska i Polacy w polskojęzycznej prasie żydowskiej II Rzeczypospolitej, Warsaw, 2015; Wielki „Maty Przeglad". Spoteczeństwo i życie codzienne w II Rzeczypospolitej w oczach korespondentów „Matego Przegladu”, Warsaw, 2018.

E-mail: alandau@op.pl. 